\title{
Secretory immunoglobulin A in pancreatic juice and pancreatic tissue of patients with chronic pancreatitis
}

\author{
J Emmrich, M Seyfarth, P Conradi, F Plath, G Sparmann, M Löhr, S Liebe
}

\begin{abstract}
Background-The predominace of secretory IgA (S-IgA) in intestinal secretions compared with blood is well established, but concentrations of this protein in pancreatic juice and its origin, especially in chronic pancreatitis, are unknown.

Aims-To investigate the role of S-IgA in chronic pancreatitis.

Patients-Twenty one patients with chronic pancreatitis (group I), three patients with proven malignancies (group II), and 12 patients without pancreatic disease (group III).

Methods-Pure human pancreatic juice was collected endoscopically in four fractions after consecutive stimulation with secretin and cholecystokinin (CCK). Samples were analysed for S-IgA, protein, trypsinogen, and proteolytic activity.

Results-The S-IgA level was significant increased in fraction 1 of pancreatic juice of group I (1210 (1411) ng/ml) compared with controls (33 (70) ng/ml). Protein concentrations and trypsinogen content were lower in group I than in the other groups. Proteolytic activity could be observed in $53 \%$ of all 133 pancreatic juice samples, but in $87 \%$ of fraction 1 . In pancreatic tissue of three patients with chronic pancreatitis both IgA and secretory component were detected by immunohistology. Expression of the secretory component by human pancreatic epithelial cells was increased in patients with chronic pancreatitis compared with normal controls. The concentration of $S-I g A$ in pancreatic juice did not correlate with the serum S-IgA level. In contrast, serum levels of S-IgA were decreased in patients with chronic pancreatitis.

Conclusion-There are high levels of S-IgA in human pancreatic juice following chronic inflammation and a protective role is suggested for this immunoglobulin. (Gut 1998;42:436-441)
\end{abstract}

Keywords: chronic pancreatitis; pancreatic juice; protease activity; protease inhibitors; secretory IgA; immunohistochemistry

Institut of Clinical Immunology,

University of Lübeck, Germany

M Seyfarth

Correspondence to: Dr Emmrich.

Accepted for publication 5 September 1997 from molecules and microorganisms to which the mucosal surfaces are exposed. The major isotype in various external secretions is secretory $\operatorname{IgA}(\mathrm{S}-\operatorname{IgA})$ consisting of secretory component (SC) and two immunoglobulin A molecules. ${ }^{12}$ The appearance of S-IgA is dependent on the interaction between subendothelial plasma cells which secrete IgA and epithelial cells which synthesise a corresponding receptor, poly Ig receptor..$^{1-4}$ Several reports have been published on immunoglobulins in human pancreatic juice with or without pancreatic disorders. ${ }^{5-8}$ However, the numbers of patients were small, and insensitive methods such as immunodiffusion were used; activation of proteases was not considered. Saito et al found SC and IgA in pancreatic juice of two patients with chronic pancreatitis and of a single patient after surgical pancreatic resection performed due to gastric cancer. ${ }^{8} \mathrm{SC}$ and IgA were measured by immunodiffusion. Protease activity was not investigated. Hayakawa et al observed increased levels of SC in pure pancreatic juice of patients with chronic pancreatitis. $^{9}$ In a pilot study we showed increased levels of the whole molecule S-IgA in endoscopically obtained pure pancreatic juice from several patients with chronic pancreatitis using an enzyme linked immunosorbent assay (ELISA).${ }^{10}$ We suggested that pancreatic epithelial cells synthesise SC and infiltrating leucocytes produce IgA. Recently, leucocyte infiltration in patients with chronic pancreatitis was analysed using immunohistochemistry. ${ }^{11}{ }^{12}$ The HLA class II antigen, DR, which is expressed by antigen processing cells, has also been found on pancreatic epithelial cells. ${ }^{11}{ }^{12}$

The purpose of the present study was to detect $\mathrm{S}-\mathrm{IgA}$ in pancreatic juice, pancreatic tissue, and serum of patients with chronic pancreatitis in comparison with normal controls. A combination of protease inhibitors was added to juice samples to avoid degradation of proteins.

\section{Materials and methods}

PATIENTS

Pancreatic juice samples of 36 patients were collected. On the basis of standard diagnostic procedures (sequential determination of serum amylase and lipase, ultrasonography, pancreozymin-secretin test, computed tomography, and endoscopic retrograde pancreatography), patients were divided into three groups. Group I consisted of 21 patients suffering from alcohol induced chronic pancreatitis, group II consisted of three patients with pancreatic malignancy, and group III consisted of 12 patients with no pancreatic disorder. Chronic pancreatitis was subclassified further into calcified (CCP, $n=11$ ) or non-calcified pancreatitis (NCP, $n=10$ ) by radiological evidence 
Table 1 Age, sex, and diagnosis of patients

\begin{tabular}{lllllll}
\hline Group & Patients $(n)$ & Female $(n)$ & Male $(n)$ & Age $(y)$ & Age range $(y)$ & Diagnosis \\
\hline I & 21 & 3 & 18 & 41 & $25-63$ & Chronic pancreatitis \\
II & 2 & 1 & 1 & 65 & 57,73 & Pancreatic carcinoma, G2 \\
& 1 & 0 & 1 & 38 & 38 & Endocrine malignancy \\
III & 1 & 0 & 1 & 45 & 45 & Cholelithiasis \\
& 11 & 6 & 5 & 49 & $33-65$ & Functional gastrointestinal disorder \\
\hline
\end{tabular}

of pancreatic calcification. Table 1 summarises age, sex, and diagnosis of patients in all three groups. Diagnostic pancreatograms were performed in all patients before pancreatic juice aspiration, which was performed separately one week later.

Pancreatic tissue was obtained from three patients with chronic pancreatitis (two with NCP, one with CCP) who underwent surgical intervention to treat biliary obstruction, pancreatic duct obstruction, and persistent pain. Three normal human pancreata were obtained after informed consent via regular multiorgan donor procedures. All pancreatic tissue was obtained as fresh surgical samples that were immediately frozen at $-80^{\circ} \mathrm{C}$ for immunohistochemistry. Portions of each sample were also prepared for routine light microscopy.

PANCREATIC JUICE

Pancreatic juice was obtained as described by our group previously. ${ }^{1314}$ The juice was sampled by direct transduodenal cannulation of the pancreatic duct under sequential stimulation by secretin (1 U/kg; Boots, Nottingham, UK) and pancreozymin (1 U/kg; Hoechst, Germany). UV absorption ( $280 \mathrm{~nm}$ ) was recorded simultaneously to estimate protein content. By means of this technique four unique fractions could be distinguished: protein rich wash out period; phase of secretin action; phase of pan-

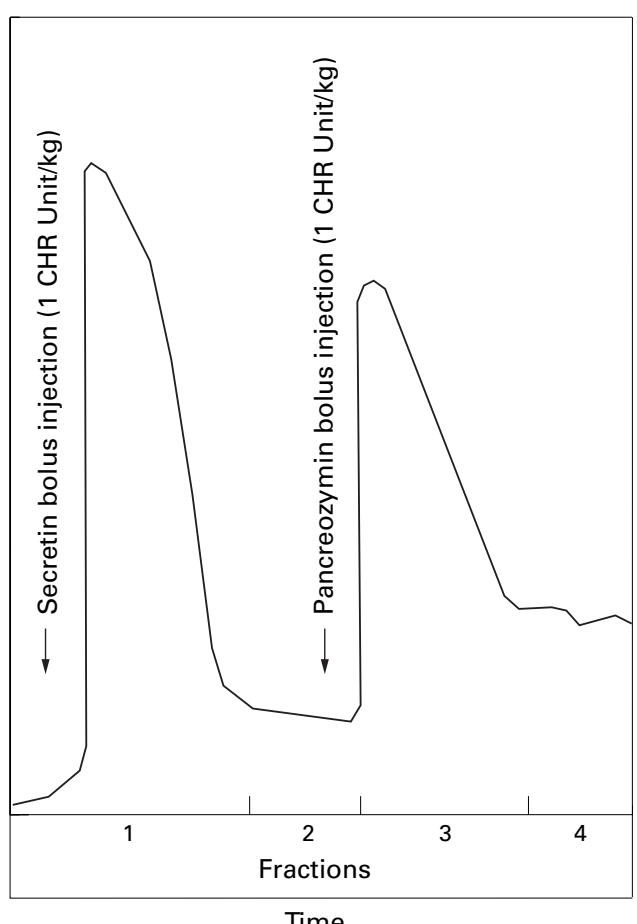

Figure 1 Absorption curve (at $280 \mathrm{~nm}$ ) and definition of fractions in pancreatic juice after stimulation by different hormones. creozymin (CCK) action; and post-CCK phase (fig 1). Samples were transferred immediately to cooled tubes and cleared by centrifugation for 10 minutes at $2000 \mathrm{rpm}$ and $4^{\circ} \mathrm{C}$. The supernatants were aliquoted and stored at $-80^{\circ} \mathrm{C}$ until further analysis. Serum samples (14 from group I and eight from group III), were obtained on completion of the pancreatic juice collection.

\section{BIOCHEMICAL METHODS}

Total protein content of fractions was determined according to the method of Lowry et $a l .{ }^{15}$ Protease activity was estimated by measuring trypsin activity using $\mathrm{N} \alpha$-benzoyl-DLarginine- $p$-nitroanilide (Boehringer, Mannheim, Germany) as substrate and by azocasein substrate reaction (azocasein kindly provided by Dr Langner, Halle, Germany). ${ }^{16}$ Integrity of pancreatic proteins was shown by measuring trypsinogen after activation with enterokinase (Sigma, St Louis, USA) according to Nagel et al. ${ }^{16}$

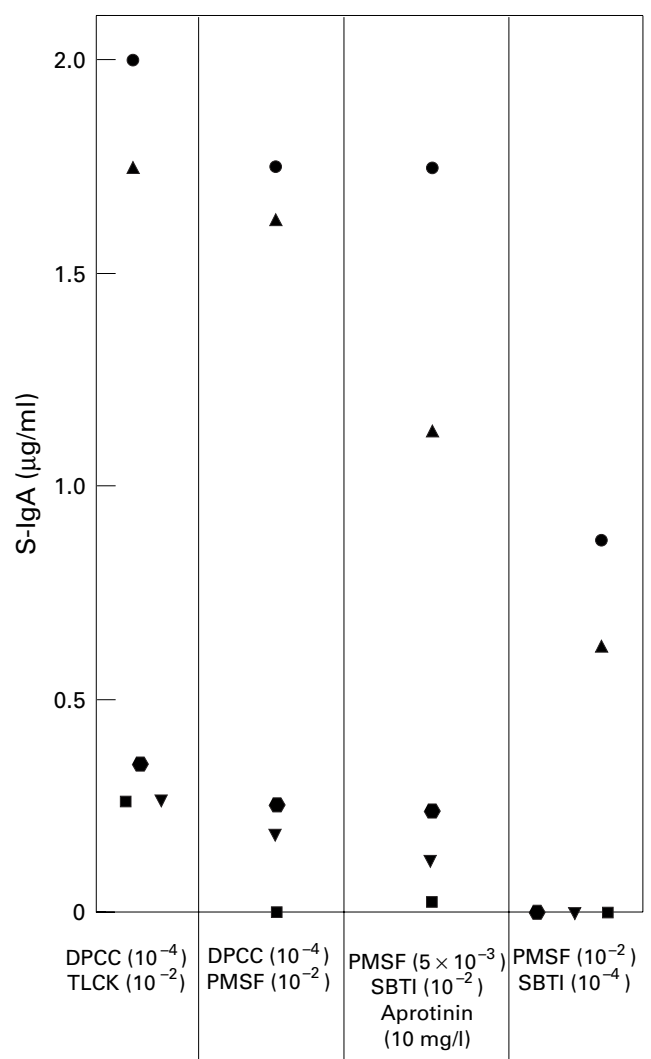

Figure 2 Influence of different combinations of proteinase inhibitors on results of the S-IgA ELISA. Identical symbols indicate identical samples of pancreatic juice. TLCK,

Na-p-tosyl-l-lysine-chloromethyl-ketone; DPCC, diphenylcarbamyl chloride; PMSF, phenylmethylsulphonyl fluoride; SBTI, soybean trypsin inhibitor. 
Table 2 Protein concentrations $(g / l)$ in fractions of pancreatic juice from patients in groups I (chronic pancreatitis, $n=16)$, II (pancreatic malignancy, $n=3$ ), and III (normal pancreas, $n=12$ )

\begin{tabular}{llll}
\hline Fraction & Group I & Group II & Group III \\
\hline 1 & $3.38(2.3)$ & $3.30(0.3)$ & $4.82(3.9)$ \\
2 & $0.83(0.6)$ & $0.34(0.2)$ & $0.69(0.4)$ \\
3 & $3.29(1.8)$ & $2.25(1.4)$ & $3.79(2.1)$ \\
4 & $1.45(0.8)$ & $0.60(0.2)$ & $1.70(0.9)$ \\
\hline
\end{tabular}

IMMUNOGLOBULINS

All pancreatic juice and serum samples were analysed in triplicate for S-IgA in a solid phase two site sandwich ELISA as described previously by our group. ${ }^{18}$ Briefly, microtitre plates were coated with monoclonal antibody against human SC (BL-HSC/III, kind gift of Dr Fiebig, Leipzig, Germany). Samples were incubated for 16 hours in triplicate in four geometric dilutions. IgA was detected by peroxidase conjugated antihuman IgA (Sevac, Prague, CSSR) antibodies with $o$-phenylene diamine (Sigma, St Louis, USA) as substrate. This ELISA had a lower sensitivity limit of 20 $\mathrm{ng} / \mathrm{ml}$. The coefficient for intra-assay variation was lower than $5 \%$; the coefficient for inter-

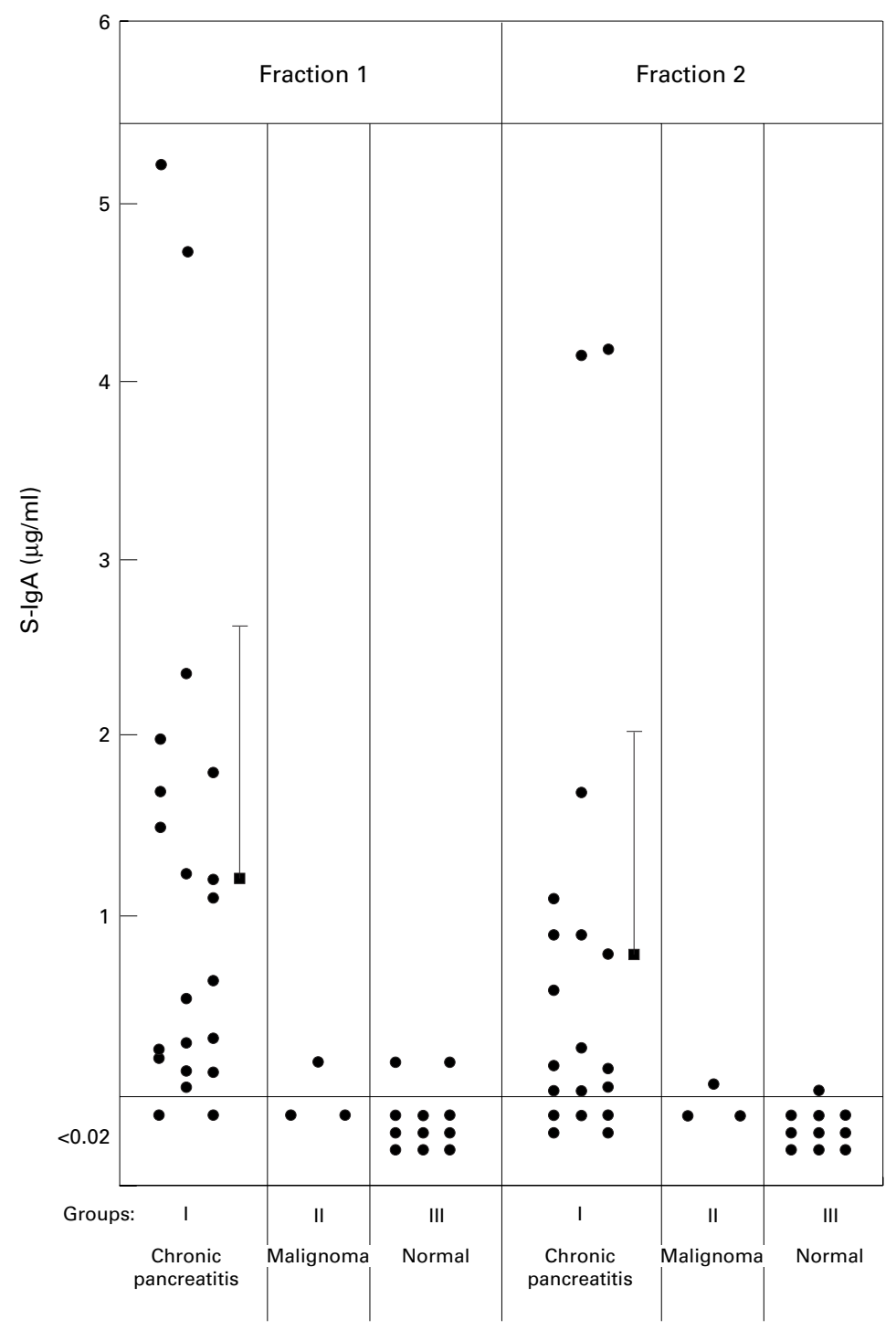

Figure 3 S-IgA concentrations in fractions 1 and 2 of pancreatic juice.
Table 3 Trypsinogen ( $\mu$ mol/l) in fractions of pancreatic juice from patients in groups I (chronic pancreatitis, $n=16)$, II (pancreatic malignancy, $n=3$ ), and III (normal pancreas, $n=12$ )

\begin{tabular}{lllr}
\hline Fraction & Group I & Group II & Group III \\
\hline 1 & $6.89(2.8)$ & $8.10(1.4)$ & $16.4(8.9)$ \\
2 & $1.86(1.5)$ & $1.32(0.2)$ & $1.89(0.7)$ \\
3 & $7.37(6.4)$ & $6.48(5.8)$ & $12.9(9.6)$ \\
4 & $2.67(1.8)$ & $3.68(2.6)$ & $5.65(3.2)$ \\
\hline
\end{tabular}

assay variation was $7.8 \%$. N $\alpha$ - $p$-tosyl-1-lysinechloromethyl-ketone (TLCK; Serva, Heidelberg, Germany) $10 \mathrm{mM}$ and diphenylcarbamyl chloride (DPCC; Serva) $10 \mathrm{mM}$ were added to avoid degradation of proteins by activated proteinases.

Immunoglobulin levels were measured in serum samples by turbidimetry using isotype specific antibodies (Behringwerke, Marburg, Germany).

IMMUNOHISTOCHEMISTRY

Monoclonal antibodies with specificity against CD3 ( $\mathrm{T}$ lymphocytes), CD22 (B lymphocytes), HLA-DR, and immunoglobulins IgG, IgM, and IgA were obtained from Dako, Denmark. Anti-CD38 (plasma cells) antibodies were from Dianova (Hamburg, Germany). Polyclonal rabbit antihuman antibody (Dako) was used to detect SC. Serial $5 \mu \mathrm{m}$ cryostat sections were stained with the alkaline phosphatase monoclonal antialkaline phosphatase (APAAP) method. ${ }^{19}$ The first primary monoclonal antibody was followed by rabbit antimouse IgG (Dako) and finally by monoclonal mouse APAAP (Dako). In the case of SC a third antibody (mouse antirabbit) was used between the primary and secondary antibody. Controls included incubation with secondary antibody or enzyme only. Alkaline phosphatase substrate contained new fuchsin, sodium nitrite, levamisole, and naphthol AS-BI (all Sigma, St Louis, USA). Cell nuclei were counterstained with Mayer's haematoxylin.

STATISTICAL ANALYSIS

To detect differences between the groups, the results were analysed by the Mann-Whitney test. In addition, correlations were searched for using the correlation coefficient. All values were expressed as mean (SD).

\section{Results}

PROTEINS AND PROTEASE ACTIVITY

Table 2 shows total protein concentrations of different pancreatic juice fractions endoscopically obtained from patients of groups I, II, and III. The protein concentration of fraction 1 was high because this fraction contains proteins

Table 4 Number of pancreatic juice fractions with protease activity measured as described in the text. Pairs of data represent active/total number of fractions from groups $I$ (chronic pancreatitis, $n=16$ ), II (pancreatic malignancy, $n=3$ ), and III (normal pancreas, $n=12$ )

\begin{tabular}{llll}
\hline Fractions & Group I & Group II & Group III \\
\hline 1 & $15 / 16$ & $2 / 3$ & $9 / 11$ \\
2 & $11 / 15$ & $1 / 3$ & $8 / 12$ \\
3 & $9 / 16$ & $0 / 3$ & $3 / 12$ \\
4 & $2 / 12$ & $0 / 3$ & $1 / 11$ \\
\hline
\end{tabular}


Table $5 \operatorname{Ig} G, \operatorname{Ig} M, \operatorname{Ig} A$, and $S$-IgA serum concentrations in groups I (chronic pancreatitis) and III (normal pancreas)

\begin{tabular}{lllll}
\hline \multirow{5}{*}{ Group } & \multicolumn{1}{l}{ Immunoglobulin } & & \\
\cline { 2 - 5 } & $\operatorname{Ig} G(g / l)$ & $\operatorname{Ig} M(g / l)$ & $\operatorname{Ig} A(g / l)$ & $S$ - $\lg A(m g / l)$ \\
\hline $\mathrm{I}(\mathrm{n}=14)$ & $12.49(5.42)$ & $2.53(1.13)$ & $3.63(1.82)$ & $6.25(3.45)$ \\
III $(\mathrm{n}=8)$ & $11.92(4.34)$ & $1.51(0.92)$ & $2.28(1.09)$ & $9.15(3.86)$ \\
\hline
\end{tabular}

Values are expressed as mean (SD).

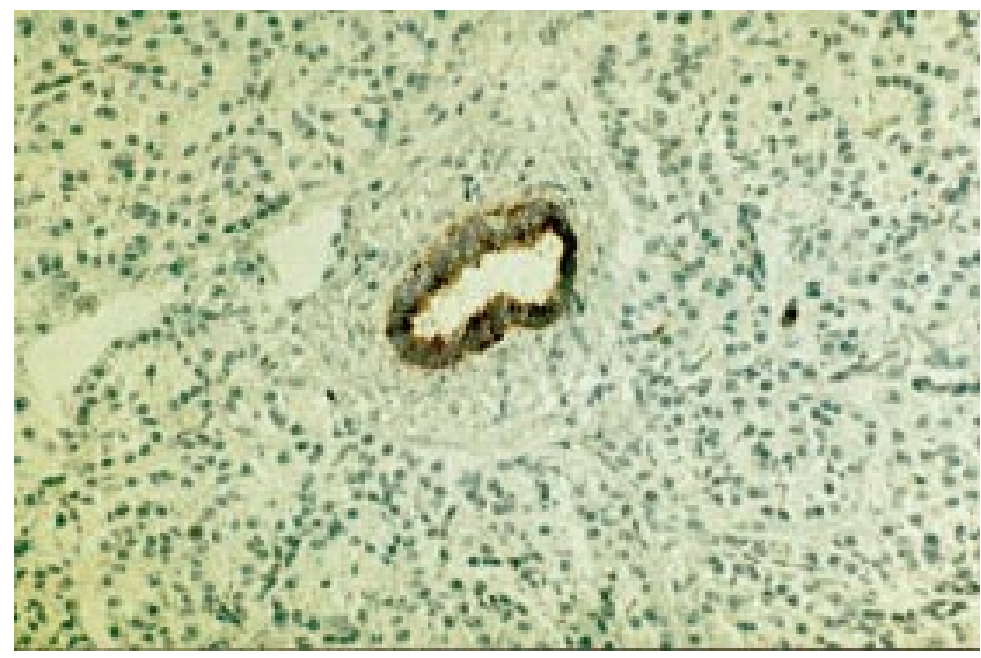

Figure 4 Immunohistochemical staining of SC in frozen tissue sections of human pancreas. In normal pancreatic tissue, SC is predominantly localised on epithelial cells of large pancreatic ducts.

which were washed out from pancreatic ductules by secretin stimulation. Fraction 3 was obtained after CCK stimulation representing secretion of pancreatic proteins by acinar cells. In normal pancreas, the output of proteins was increased in fraction 1 compared with fraction 3 . In chronic pancreatitis, the protein concentration was nearly the same between fractions 1 and 3. Protein levels of fractions 1,3 , and 4 were lower than in normal patients, but the difference was not significant.

To compare the content of inactive enzyme protein in pancreatic juice, trypsinogen was measured. Compared with protein content, similar results were observed regarding distribution of trypsinogen in fractions 1 to 4 (table

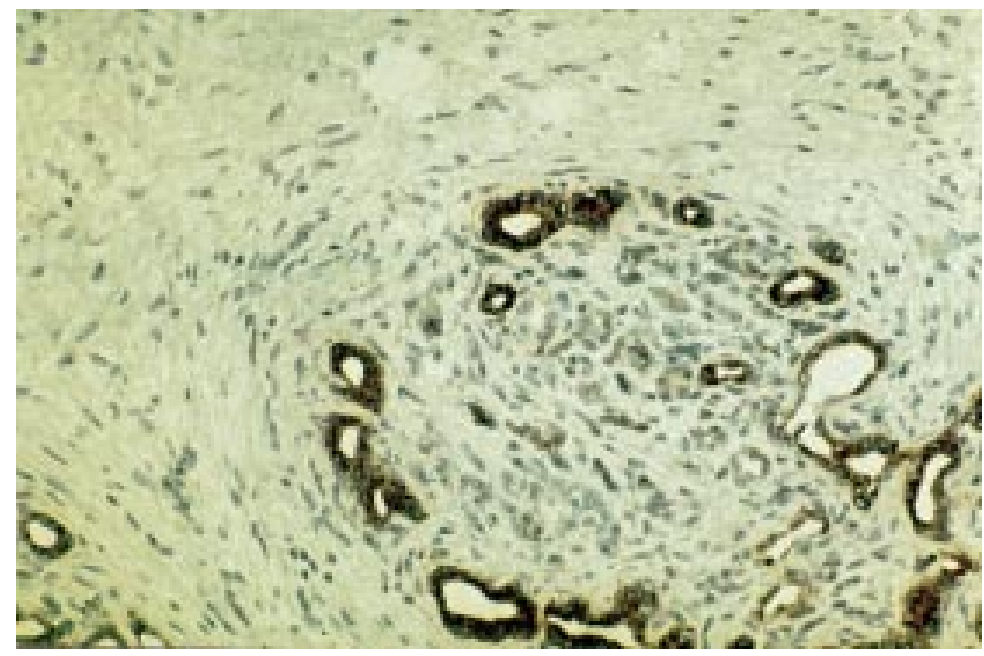

Figure 5 Immunohistochemical staining of SC in pancreatic tissue from a patient with chronic pancreatitis. In an area of acinar destruction and inflammatory cells, small ducts are immunoreactive for $S C$.
3). Trypsinogen levels were lower in patients of group I than in controls of group III. On average, values of fraction 1 in group I were lower than those of fraction 3. The tumour patients of group II did not show any differences compared with other patients.

Table 4 shows that a large number of pancreatic juice samples were activated. There was no relation to conditions of sample collection, such as time for cannulation of pancreatic duct, time of investigation, or severity of chronic pancreatitis. Moreover, there were no differences between patient groups regarding number of activated samples.

S-IgA IN PANCREATIC JUICE AND SERUM

During incubation in the ELISA the possibility of protease influence is increased. Therefore, it is important to use an optimal combination of protease inhibitors. Figure 2 shows the influence of different inhibitors on ELISA results. According to these results we used the combination of DPCC $\left(10^{-4} \mathrm{M}\right)$ and TLCK $\left(10^{-2} \mathrm{M}\right)$ for our experiments.

S-IgA was found predominantly in fraction 1. The concentration of this protein in other pancreatic juice fractions of the same collection was lower in every case. It is concluded that S-IgA was not secreted after CCK stimulation. It was only washed out by secretin stimulation. S-IgA was measured in 133 pancreatic juice samples corresponding to different fractions of pancreatic juice obtained from 36 patients. The data clearly show that raised levels of S-IgA were found in fraction 1 (1210 (1411) ng/ml) in the chronic pancreatitis group (fig 3 ). Very low concentrations of S-IgA could be detected in fraction 1 in three cases in the control group (33 (70) $\mathrm{ng} / \mathrm{ml}$ ) and in a single case in group II. Despite the wide range of values for S-IgA in pancreatic juice there is a significant difference between group I and the other two groups. In particular, S-IgA concentrations were high in cases of chronic pancreatitis with obstructed ductules and high viscosity of pancreatic juice. There were no differences between subgroups of chronic pancreatitis such as NCP and CCP regarding the content of S-IgA in pancreatic juice samples.

Corresponding serum immunoglobulin and S-IgA results were available in 22 patients of our patient population (table 5). Patients with chronic pancreatitis (group I) had elevated mean serum concentrations of $\operatorname{IgM}$ and $\operatorname{IgA}$ compared with patients without pancreatic disorders (group III). The mean serum concentration of S-IgA was lower in group I patients. Due to the small number of individuals statistical differences could not be established.

There were no correlations between serum levels of S-IgA and concentrations in pancreatic juice.

TISSUE

Three samples of normal pancreatic tissue were compared with three samples of chronically inflamed pancreas. In the normal pancreas there were only a few $\mathrm{T}$ lymphocytes, single plasma cells, and no B lymphocytes. T 


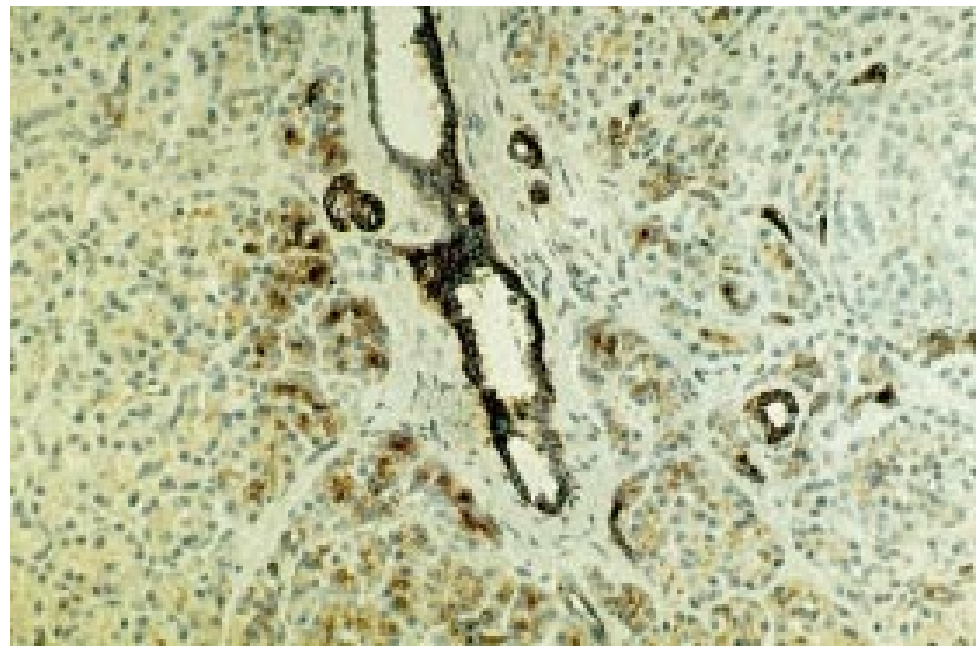

Figure 6 Immunohistochemical staining of pancreatic duct epithelial cells including centroacinar cells in chronically inflamed pancreatic tissue.

cells were diffusely distributed between acinar cells. Duct epithelial cells mostly showed no expression of HLA-DR and SC. Occasionally single cells in the epithelial cell layer were positive for these two antigens (fig 4).

In diseased tissue a variable amount of infiltrating mononuclear leucocytes was detected with a predominance of $\mathrm{T}$ lymphocytes. Only about $10 \%$ carried CD22. A large number of inflammatory mononuclear cells and epithelial cells expressed HLA-DR. In addition, nearly all epithelial cells and several centroacinar cells were positive for SC (figs 5 and 6).

We could detect IgG, IgM, and IgA in samples from patients with chronic pancreatitis. There were no differences between the three classes of immunoglobulins. In samples of normal pancreatic tissue immunoglobulins were not detected.

\section{Discussion}

For several years it has been possible to obtain pure pancreatic juice by special endoscopic techniques. We developed a definite method to collect and characterise pancreatic juice by measuring UV absorption to indicate amounts of protein. ${ }^{13}$ This technique allows us to divide the juice into certain defined fractions and to compare juice samples of patients because pancreatic juice flow rate is different between patients. Therefore, all results are expressed in relation to the four juice fractions obtained as described above (fig 1).

In fraction 1 mean values of protein and trypsinogen were lower in patients with chronic pancreatitis compared with control subjects. In fraction 2 no differences could be detected between patients with chronic pancreatitis and control subjects. Fraction 3 represented proteins which were released from acinar cells after stimulation with CCK. In control subjects mean values of protein and trypsinogen were lower in fraction 3 than in fraction 1 . In patients with chronic pancreatitis there was only a slight difference in protein content between fractions 1 and 3. Trypsinogen concentration was increased in fraction $3 \mathrm{com}$ pared with fraction 1 in group I. However, the differences were not statistically significant because of high standard deviations.

Another problem is the protease activity in pancreatic juice. Many samples contain active proteases which lead to degradation of proteins and disturb detection systems. Protease inhibitors were therefore added to juice samples. ${ }^{20-22}$ However, protease activity was not measured and therefore it was not known when the capacity of the inhibitors was overloaded. We used the combination of TLCK and DPCC for inhibiting proteases and we measured protease activity. We were thus able to show that proteolytic activity was often present.

Our study confirmed an earlier report of the detection of S-IgA in pure pancreatic juice as a good marker for chronic pancreatitis. ${ }^{10}$ Brasher et al obtained pancreatic juice from two patients with traumatic pancratic fistula. ${ }^{5}$ In these samples the secretory component was absent. This finding is in agreement with our results of detectable S-IgA concentrations only in patients with chronic pancreatitis. Using duodenal secretions Finkler et al showed increased IgA concentrations in the duodenum of patients with chronic pancreatitis and pancreatic carcinoma. ${ }^{7}$ Elevated levels of nonsecretory immunoglobulins were found by Clemente $e t a l^{620}$ in pancreatic juice of patients with chronic pancreatitis. Taken together these studies indicated variations of IgA levels depending on pancreatic disorders.

We could clearly show that S-IgA levels were elevated in pancreatic juice from patients with chronic pancreatitis. However, with regard to the diagnostic potential of pancreatic juice S-IgA it has to be considered that the majority of patients with chronic pancreatitis in our study were suffering from advanced disease. Therefore, we cannot make any firm statement regarding the value of S-IgA levels for diagnosis at an early stage and for the prognosis of the disease. Moreover, there were wide differences in concentrations of SC and S-IgA in the reported studies, probably due to differences between patients as well as difficulties regarding collection and handling of pancreatic juice. Hayakawa et al measured SC in concentrations from 1-60 $\mu \mathrm{g} / \mathrm{ml}$. Saito et al reported levels of IgA in pancreatic juice of $10-49 \mu \mathrm{g} / \mathrm{ml}$. For whole molecule S-IgA our results ranged between 0.01 and $5.21 \mu \mathrm{g} / \mathrm{ml}$.

Saito et $a l^{8}$ reported the detection of SC in the pancreatic epithelium with features characteristic of endocytotic, SC mediated transfer of IgA in agreement with an immunofluorescence study by Tourville et al. ${ }^{23}$ However, they could not establish a definite source of IgA in human pancreatic tissue because they found $\operatorname{IgA}$ in pancreatic juice of normal controls and no infiltrating cells in the corresponding pancreatic tissue. Normal pancreatic tissues investigated by these authors were obtained from patients who underwent surgical resection because of gastric cancer disease without pancreatic disorders. Any influence of cancer on pancreatic acinar and/or epithelial cells cannot be excluded. We did not detect elevated levels of S-IgA in pancreatic juice in patients with normal pancreas. In patients with chronic 
pancreatitis with increased immunoglobulin levels in pancreatic juice, B cells and plasma cells were present in pancreatic tissue as shown by immunohistochemistry. ${ }^{12}$ In these patients we could show SC in epithelial cells and in centroacinar cells which functionally belong to the duct system of the pancreas. Therefore, it is suggested that in chronic pancreatitis IgA and SC were expressed locally by plasma cells and epithelial cells in pancreatic tissue.

Increased expression of MHC class II molecules on pancreatic duct epithelial cells as described elsewhere indicated a state of activation. ${ }^{11}{ }^{12} 24$ In this study we showed HLA-DR as well as SC on pancreatic duct cells. In cases of chronic pancreatitis we also found SC expressed by centroacinar cells. Candidates for stimulation of HLA-DR and SC expression are cytokines such as interferon $\gamma .{ }^{25}$

We found elevated mean levels of IgA but decreased levels of S-IgA in serum of patients with chronic pancreatitis. There were no correlations with S-IgA levels in pancreatic juice. In patients with chronic pancreatitis, raised serum levels of IgA have also been shown by other investigators. ${ }^{2627}$

As S-IgA has been detected in pancreatic juice its function in this secretion can be appreciated. $^{28}$ SC stabilises polymeric IgA covalently linked to the S-IgA complex. This molecule has been shown to bind trypsin and chymotrypsin in an antibody independent manner that inactivates the enzymes. ${ }^{29} \mathrm{~S}-\mathrm{IgA}$ is therefore more suitable than other immunoglobulins to protect pancreatic tissue against a variety of viral and bacterial mucosal pathogens. Numerous studies in animal models and in humans have provided evidence that this protection against microorganisms is generally correlated with levels of IgA antibodies in secretions. ${ }^{26}$ Chronic pancreatitis is characterised by perilobular and interlobular fibrosis, altered composition of pancreatic secretions, and protein plugs in the ductules. Occasionally, duct epithelium may be hyperplastic. Pancreatic ducts are distorted, distended irregularly, and obstructed followed by disturbed secretion drain. ${ }^{30-32}$ Infection in this obstructed duct system may be dangerous for the host so that an effective protection is necessary. Further studies should show relations between immunological mechanisms and pathogenesis of chronic pancreatitis.

We would like to thank Mrs I Arendt, I Weber, and I Meiske for technical assistance. We are also grateful to the staff of the endoscopy unit for assistance during the collection of patient samples. This work was supported by a grant from the Bundesministerium für Forschung und Technologie (BMFT-DFVLR $01 / \mathrm{ZZ} / 1902$ ) and by Fonds of Verband der Chemischen Industrie. Part of this work has been presented at the Digestive Disease Week 1993 (Gastroenterology 1992;102:A620).

1 Mestecky J, Russell MW, Jackson S, et al. The human IgA system: a reassessment. Clin Immunol Immunopathol 1986;40:105-14.

2 Mestecky J, McGhee JR. Immunoglobulin A (IgA): Molecular and cellular interactions involved in IgA biosynthesis and immune response. Adv Immunol 1987;40:153thesis

3 Brandtzaeg P. Role of J chain and secretory component in receptor-mediated glandular and hepatic transport of immunoglobulins in man. Scand F Immunol 1985;22:111-46.
4 Brandtzaeg P, Prydz H. Direct evidence for an integrated function of J chain and secretory component in epithelial function of $J$ chain and secretory component in epithe
transport of immunoglobulins. Nature 1984;311:71-3.

5 Brasher GW, Dyck WP, Hall FF, Spiekermann AM. Immunoglobulin characterization of human pancreatic fluid. $\mathrm{Am}$ f Dig Dis 1975;20:454-9.

6 Clemente F, Ribeiro T, Colomb E, et al. Comparaison des proteines de sucs pancreatiques humains normaux et pathologiques. Dosages des proteines seriques et mise en evidence d'une proteine particuliere dans la pancreatite chronique calcificante. Biochim Biophys Acta 1971;251: 456-66.

7 Finkler NJ, Palmer M, Gonda M, et al. Nephelometric determination of immunoglobulins in exocrine pancreatic secretion-studies on patients with or without pancreatic disease. Mount Sinai F Med 1979;46:339-40.

8 Saito H, Kasajima T, Nagura H. An immunocytochemical study on secretory mechanism of IgA in human pancreas. Acta Pathol fpn 1985;35:87-101.

9 Hayakawa T, Kondo T, Shibata $\mathrm{T}$, et al. Secretory component and lactoferrin in pure pancratic juice in chronic pancreatitis. Dig Dis Sci 1993;38:7-11.

10 Emmrich J, Conradi P, Seyfarth M, et al. Secretory immunoglobulin A levels in pure pancreatic juice. Digestion 1992;52:79-80.

11 Bedossa P, Bacci J, Lemaigre G, et al. Lymphocyte subsets and HLA-DR expression in normal pancreas and chronic pancreatitis. Pancreas 1990;5:415-20.

12 Emmrich J, Nausch M, Seyfarth M, et al. Immunohistochemical typing of leukocytes in normal pancreas and chronic pancreatitis. Digestion 1993;54:274-5.

13 Liebe S, Weber J, Siegmund E, et al. Untersuchungen an reinem menschlichen Pankreassekret, methodische Aspekte der Sekretentnahme und Befundinterpretation. Dtsch $Z$ Verdau Stoffwechselkr 1986;46:45-52.

14 Liebe S, Siegmund E, Rehpennig W. Veränderungen im reinen menschlichen Pankreassaft bei chronischer Pankreatitis. Gastroenterol f 1990;50:129-34.

15 Lowry $\mathrm{OH}$, Rosebrough NJ, Favo NL, et al. Protein measurement with the Folin phenol reagent. 7 Biol Chem 1951;193:265-75.

16 Nagel W, Willig F, Peschke W, et al. Über die Bestimmung on Trypsin und Chymotrypsin mit Aminosäure-pnitroaniliden. Hoppe-Seylers Z Physiol Chem 1989;340:1-10.

17 Langner J, Wakil A, Zimmermann M, et al. Aktivitätsbestimmung proteolytischer Enzyme mit Azokasein als Substrat. Acta Biol Med Germ 1973;31:1-18.

18 Seyfarth M, Brock J, Hein J. Wert der s-IgA-Bestimmung bei ausgewählten Krankheitsbildern. In: vonBaehr $\mathrm{R}$, Felber HP, Porstmann T, eds. Monoklonale Antikörper. Wien-New York: Springer-Verlag, 1989:143-61.

19 Cordell JL, Falini B, Erber WN, et al. Immunoenzymatic labeling of monoclonal antibodies using immune complexes of alkaline phosphatase and monoclonal antialkaline phosphatase (APAAP complexes). I Histochem Cytochem 1984;12:219-29.

20 Clemente F, Ribeiro T, Figarella C, et al. Albumine, IgG et IgA dans le suc pancreatique humain normal chez l'adulte. Clin Chim Acta 1971;33:317-24.

21 Goodale RL, Condie RM, Dressel TD, et al. A study of secretory proteins, cytology and tumor site in pancreatic cancer. Ann Surg 1979;189:340-4.

22 Goodale RL, Condie RM, Gajl-Peczalska K, et al. Clinical and secretory differences in pancreatic cancer and chronic pancreatitis. Ann Surg 1981;194:193-8.

23 Tourville DR, Adler RH, Bienenstock J, et al. The human secretory immunoglobulin system: immunohistological localization of $\gamma \mathrm{A}$, secretory "piece", and lactoferrin
mal human tissues. $\mathcal{F}$ Exp Med 1969;129:411-23.

24 Mayer L, Eisenhardt D, Salomon P, et al. Expression of class-2 molecules on intestinal epithelial cells in humans. Gastroenterology 1991;100:3-12.

25 Phillips JO, Everson MP, Moldoveanu Z, et al. Synergistic effect of IL- 4 and IFN- $\gamma$ on the expression of polymeric Ig receptor (secretory component) and IgA binding by human epithelial cells. F Immunol 1990;145:1740-4.

26 Bank S, Novis BH, Dowdle E, et al. Serum immunoglobulins in calcific pancreatitis. Gut 1973;14:723-5.

27 Schütt C, Zastrow R, Eggers G, et al. Immunstatus bei Patienten mit chronischer Pankreatitis. I. Eine Querschnittsstudie der humoralen und zellulären Immunität. Allergie u Immunol 1980;26:222-41.

28 Kilian M, Russell MW. Function of mucoal immunoglobulins. In: Ogra PL, Strober W, Mestecky J, McGhee J, Lamm ME, Bienenstock J, eds. Handbook of mucosal immunology. San Diego-New York-Boston: Academic Press, 1994:12737.

29 Shim BS, Kang YS, Kim WJ, et al. Self-protective activity of colostral IgA against tryptic digestion. Nature 1969;222: $787-8$.

30 diMagno EP, Layer P, Clain JE. Chronic pancreatitis. In: Go VLW, Lebenthal E, diMagno EP, Reber HA, Gardner JD, Scheele GA, eds. The pancreas. Biology, pathobiology, and disease. New York: Raven Press, 1993:665-706.

31 Klöppel G. Pathology of chronic pancreatitis and pancreatic pain. Acta Chir Scand 1990;156:261-5.

32 Klöppel G, Maillet B. The morphological basis for the evolution of acute pancreatitis into chronic pancreatitis. Virchows Archiv 1992;420:1-4. 